\title{
Peningkatan Ekspresi IFN- $\uparrow$ pada Paru Mencit yang Diinduksi Protein Adhesin 38- kDa Mycobacterium tuberculosis dan ISCOM per Oral
}

\author{
Increasing Expression of IFN- $\gamma$ Lung Mice Induced with Mycobacterium Tuberculosis Adhesin 38- \\ Kda Protein and Oral ISCOM
}

\author{
M Fahrul Udin, Wisnu Barlianto, HMS Chandra Kusuma \\ Laboratorium IImu Kesehatan Anak Rumah Sakit Umum Dr. Saiful Anwar Malang
}

\begin{abstract}
ABSTRAK
Studi menemukan bahwa vaksin tuberkulosis memberikan respon imun seluler bervariasi terhadap hemaglutinin protein $38 \mathrm{kDa}$ M. tuberkulosis, suatu protein adhesin pada enterosit tikus. Protein tersebut dapat menginduksi sekresi S-lgA ke dalam lumen usus dan lumen bronkiolus. Immune stimulating complex (ISCOM) adalah bahan pembantu yang efektif meningkatkan respon kekebalan. Ekspresi IFN- $\gamma$ menunjukkan respon imun seseorang terhadap mikroba seperti virus dan bakteri serta produknya. Penelitian ini bertujuan untuk mengetahui bahwa pemberian 38-kDa protein adhesin dengan atau tanpa kombinasi ajuvan ISCOM secara oral dapat menginduksi ekspresi IFN- $\gamma$ pada jaringan paru mencit BALB/c. Metode eksperimental dilakukan dengan 4 kelompok, yaitu kelompok kontrol, kelompok terpapar protein adhesin 38$\mathrm{kDa}$, kelompok yang hanya terpapar ajuvan ISCOM dan kelompok terpapar kombinasi protein adhesin 38-kDa dengan ISCOM. Ekspresi IFN- $\gamma$ diukur dengan pewarnaan imunohistokimia. Analisis statistik dengan Kruskall Wallis menunjukkan bahwa terdapat perbedaan ekspresi IFN- $\gamma$ pada semua kelompok perlakuan. Uji perbandingan multipel Mann Whitney menyatakan bahwa terdapat peningkatan ekspresi IFN- $\gamma$ secara signifikan dalam kombinasi protein adhesin dengan ajuvan ISCOM (mean $\pm S D=126 \pm 17, p=0,000$ ) bila dibandingkan dengan kelompok lain. Paparan dengan ISCOM saja mampu menginduksi ekspresi IFN- $\gamma$ secara signifikan bila dibandingkan dengan kontrol $(p=0,000)$. Pemberian protein adhesin $38 \mathrm{kDa}$ M. tuberculosis mampu menstimulasi ekspresi IFN- $\gamma$ pada jaringan paru mencit BALB/c, dan penambahan ISCOM akan meningkatkan efek.
\end{abstract}

Kata Kunci: 38-kDa adhesin protein, interferon gamma, Mycobacterium tuberculosis, oral vaccination, paru

\begin{abstract}
Previous studies showed that tuberculosis vaccine induced a cellular immune response of $38-k D a$ M. tuberculosis hemagglutinin protein which was found in mice enterocytes. It can induce S-IgA secretion into the intestinal lumen and bronchiolus. It is known that the ISCOM is an effective adjuvant enhances the immune response. Interferon(IFN) expression mainly occurs as a response to the microbes, like-viruses and bacteria, and their products. This study aimed to investigate the impact of 38-kDa adhesin protein administration with or without oral adjuvant ISCOM to the IFN- $\mathrm{v}$ expression in lung tissue of BALB/c mice. An experimental design was performed in 4 groups: control group, intervention group with 38-kDa protein adhesion administration, ISCOM adjuvant administration and combination of 38-kDa protein adhesin with ISCOM. Expression of IFN-y was measured by immunohistochemical staining. Kruskall Wallis analysis identify significant difference of IFN-yexpression among all treatment groups $(p=0,00)$. The Mann Whitney test stated that identify significant increasing of IFN-vexpression in group with combination of protein adhesin and oral adjuvant ISCOM (mean $\pm S D=126 \pm 17$; $p=0,000$ ) when compared with the other groups. Interestingly exposure with ISCOM only has potential effect in inducing IFN-y expression significantly when compared to controls $(p=0,000)$. It can be concluded that the administration of protein adhesin $38 \mathrm{kDa}$ M tuberculosis will stimulate IFN-y expression in the lung tissue of $B A L B / c$ mice, and the addition of ISCOM will increase the impact.
\end{abstract}

Keywords: 38-kDa adhesin protein, interferon gamma, lung, Mycobacterium tuberculosis, oral vaccination

Jurnal Kedokteran Brawijaya, Vol. 28, No. 1, Februari 2014; Korespondensi: M Fahrul Udin. Laboratorium Ilmu Kesehatan Anak Rumah Sakit Umum Dr. Saiful Anwar Malang, Jl. Jaksa Agung Suprapto No. 2 Malang Tel. (0341) 366242 Email: udinprimahusada@gmail.com 


\section{PENDAHULUAN}

Tuberkulosis (TB) merupakan masalah kesehatan di seluruh dunia karena angka morbiditas dan mortalitasnya yang tinggi. Diperkirakan 95\% kasus TB dan 98\% kematian akibat TB didunia, terjadi pada negara berkembang. Penyakit yang dapat disebabkan oleh $M$. tuberculosis, $M$. bovis atau $M$. africanum ini telah dinyatakan sebagai kedaruratan global oleh WHO pada tahun 1993. Hal ini didasarkan pada laporan epidemiologi global TB. Setiap tahun TB menyebabkan hampir dua juta kematian dan diperkirakan saat ini $1 / 3$ penduduk dunia terinfeksi kuman TB (yang mungkin akan berkembang menjadi penyakit TB di masa mendatang) (1). Berdasarkan Global Tuberculosis Control: surveillance, planning, financing: WHO report 2011, WHO memperkirakan bahwa pada tahun 2006 terdapat 9,24 juta penderita TB diseluruh dunia, pada tahun 2007 jumlah penderita naik menjadi 9,27 juta jiwa. Hingga tahun 2009 angka penderita TB menjadi 9,4 juta jiwa. Pada tahun 2010, ada 8,8 juta (kisaran,8,5-9,2 juta) insiden kasus TB 1,1 juta (kisaran 0,9-1,2 juta) kematian akibat TB di antara orang dengan HIV-negatif dan tambahan 0,35 juta (kisaran 0,32-0,39 juta) kematian TB terkait HIV (2).Dari 9 juta kasus baru TB di seluruh dunia, 1 juta adalah anak usia<15 tahun (3). Dari berbagai presentase semua kasus TB pada anak berkisar antara 3\% sampai $25 \%$ (4).

Indonesia menduduki peringkat kelima di antara 22 negara yang digolongkan dalam high burden countries, setelah India dan China (2). Di Indonesia, TB merupakan masalah utama kesehatan masyarakat. Diperkirakan pada tahun 2004, setiap tahun ada 539.000 kasus baru dan kematian 101.000 orang. Insidensi kasus TB BTA positif sekitar 110 per 100.000 penduduk. Hasil survei prevalensi TB di Indonesia tahun 2004 menunjukkan bahwa angka prevalensi TB BTA positif secara nasional 110 per 100.000 penduduk. Mengacu pada hasil surveiprevalensi tahun 2004, diperkirakan penurunan insiden TB BTA positif secara nasional 3-4\% setiap tahunnya (1).

Resistensi terhadap lini pertama terapi TB seperti isoniazid maupun rifampisin disebut TB-MDR (multi drug resistance). Peningkatan angka kesakitan dan kematian akibat TB, sertajumlah pasien TB yang di diagnosis dengan TB-MDR pada 5 tahun terakhir mendorong untuk dilakukannya penelitian ini (2). Prevalensi TB-MDR pada kasus pengobatan ulang bervariasi antara 30\%-80\% bergantung pada negara terkait (5). Indonesia termasuk dalam 27 negara TB-MDR yang diperkirakan oleh WHO pada tahun 2008 memiliki setidaknya 4.000 kasus TBMDR yang muncul setiap tahun (6). Hasil penelitian di Jakarta mendapatkan $>4 \%$ kasus baru TB-MDR (4). Oleh karena itu, saat ini pengembangan vaksin TB yang efektif menjadi prioritas penting (7).

Vaksin Bacille Calmette Guerin (BCG) saat ini digunakan untuk melawan TB, namun tidak sepenuhnya efektif, dan tidak dapat mencegah reaktivasi TB laten pada orang yang membawa bakteri tetapi tidak memiliki gejala penyakit. Berbagai penelitian melaporkan proteksi dari vaksinasi BCG untuk pencegahan penyakit TB berkisar antara 0\%$80 \%$. Secara umum diperkirakan daya proteksi BCG hanya $50 \%$, dan vaksinasi BCG hanya mencegah terjadinya TB berat, seperti milier dan meningitis TB. Daya proteksi BCG terhadap meningitis TB 64\%, dan milier TB 78\% pada anak yang mendapat vaksinasi (4). Beberapa penelitian telah dilakukan untuk menemukan vaksin TB menunjukkan hasil yang bervariasi terhadap respon imun seluler yang dihasilkan. Sugiharta et al menemukan bahwa protein hemaglutinin BM $38 \mathrm{kDa}$ M. tuberculosis merupakan protein adhesin pada enterosit mencit, dan pemberian protein adhesin hemaglutinin BM $38 \mathrm{kDa} M$. tuberculosis per oral pada mencit BALB/c dapat menginduksi sekresi SIgA ke dalam lumen usus dan lumen bronkhiolus. Upaya karakterisasi protein adhesin akan memperoleh antigen yang merangsang produksi S-IgA spesifik ke dalam lumen saluran cerna dan nafas, untuk mencegah perlekatan dengan protein reseptor. Protein adhesin M. tuberculosis belum banyak diteliti namun berpotensi imunogenik untuk membentuk antibodi spesifik dan dapat menghambat proses adhesi dan kolonisasi, yang mempunyai peran penting sebagai vaksin mucosal (8).

Telah diketahui bahwa ISCOM efektif meningkatkan respon imun. Hal penting dalam mekanisme peningkatan respon imun adalah kemampuan ajuvan (termasuk ISCOM) untuk berinteraksi dengan Antigen Presenting Cells (APC). Beberapa studi telah dilakukan dengan pemberian ISCOM secara peroral, salah satunya adalah Sjolander et al yang membuktikan bahwa imunisasi per oral OVA-ISCOM memberikan hasil yang sama dengan pemberian per injeksi (9). Produksi interferon (IFN)- $\gamma$ terutama terjadi sebagai bentuk respon terhadap keberadaan mikroba, sepert virus dan bakteri, serta hasil produknya. IFN- $\gamma$ dapat terpicu oleh molekul pengikat (binding molecule) yang unik pada mikroba, seperti glikoprotein virus, RNA virus, endotoksin bakteri (lipopolisakarida), flagela bakteri, atau motif CpG, melalui pengikatan terhadap reseptor tertentu, seperti Toll-like receptor (TLR) atau reseptor sitoplasmik retinoic acidinducible gene-I (RIG-I) atau melanoma differentiationassociated protein 5 (MDA5) (10). Interferon- $\gamma$ memegang peranan penting dalam mengatur respon imun yang dimediasi oleh sel terhadap infeksi $M$. tuberculosis (11). Interferon- $\gamma$ merupakan pertahanan penting terhadap $M$. tuberculosis dan didapatkan infeksi mycobakterium berat pada pasien dengan defek pada jalur pensinyalan IFN- $\gamma$ (12). Penelitian lanjutan perlu dilakukan untuk mengamati pengaruh pemberian protein adhesin 38-kDa $M$. tuberculosis yang diberikan melalui oral terhadap imunitas seluler, dengan menilai ekspresi IFN- $\gamma$ pada paru sebagai lokasi primer infeksi M. tuberculosis.

\section{METODE}

Penelitian ini merupakan penelitian eksperimental yang bertujuan untuk membuktikan bahwa protein adhesin 38$\mathrm{kDa} M$. tuberculosis dapat menginduksi respons imun pada usus dan paru mencit BALB/c. Rancangan penelitian yang digunakan adalah Posttest Control Group Design. Gambaran histopatologi usus dan paru dianalisis secara kuantitatif dan deskriptif. Untuk melihat perbedaan IFN- $\gamma$ antara kelompok kontrol (tidak mendapat perlakuan) dengan kelompok perlakuan. Pada kelompok perlakuan mencit mendapat imunisasi oral protein adhesin $38 \mathrm{kDa} M$. tuberculosis dan/atau ajuvan immune stimulating complexes (ISCOM) digunakan uji non-parametrik KruskalWallis dengan tingkat kepercayaan $95 \%$ atau $\alpha=0,05$. Kemudian untuk melihat perbedaan ekspresi interferon gamma pada tiap-tiap kelompok dilanjutkan dengan uji beda Mann Whitney. 


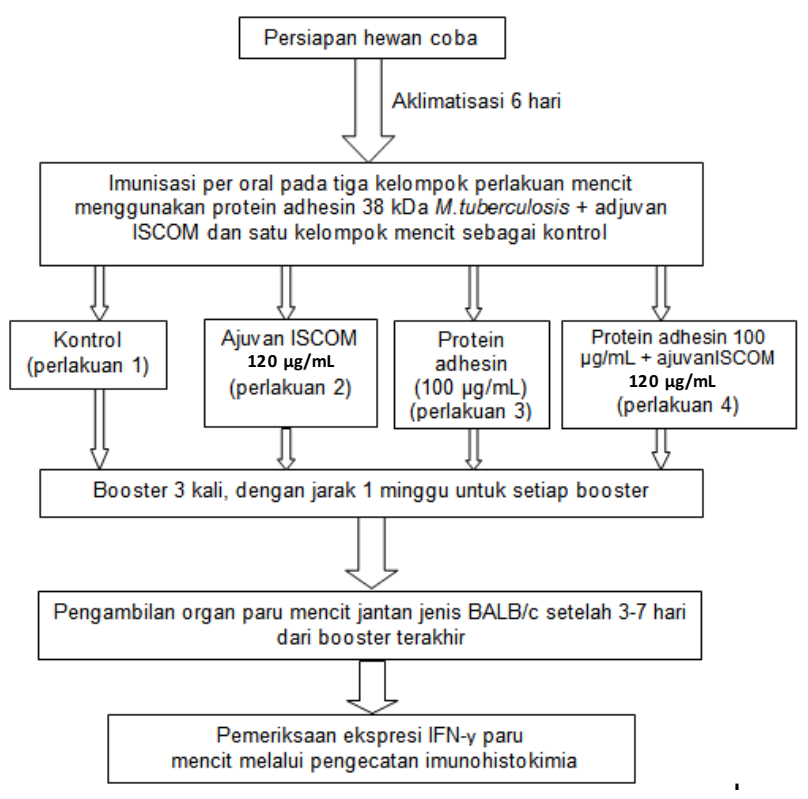

Gambar 1. Alur penelitian

\section{HASIL}

Gambar 2 menunjukkan gambaran sediaan histokimia pada semua kelompok perlakuan. Ekspresi interferon gamma dibuktikan dengan terekspresinya warna coklat.
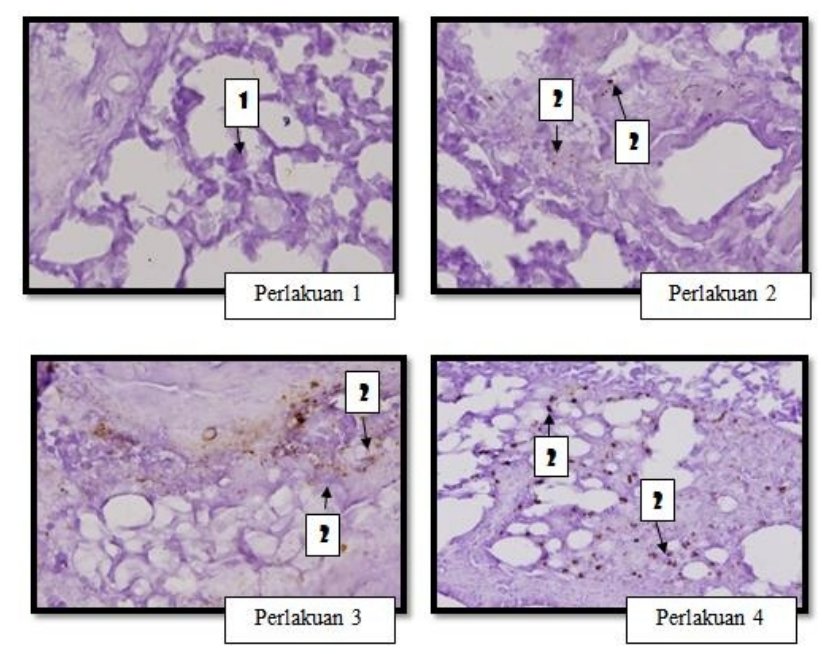

Gambar 2. Hasil pengecatan imunohistokimia pada tiap kelompok perlakuan

Keterangan:

Perlakuan 1 adalah kontrol tanpa perlakuan apapun.

Perlakuan 2 ajuvan ISCOM $120 \mu \mathrm{g} / \mathrm{mL}$

Perlakuan $3100 \mu \mathrm{g} / \mathrm{mL}$ protein adhesion 38 kDa Mycobacterium tuberculosis,

Perlakuan $4100 \mu \mathrm{g} / \mathrm{mL}$ adhesein $38 \mathrm{KDa}$ Mycobacterium tuberculosis dan ajuvan ISCOM $120 \mu \mathrm{g} / \mathrm{mL}$

Pengamatan ekspresi IFN- $\gamma$ dalam plasma darah dari keempat kelompok perlakuan disajikan pada Gambar 3. Hasil menunjukkan bahwa pada kelompok perlakuan memberikan gambaran ekspresi IFN- $\gamma$ yang semakin besar dengan penambahan perlakuan.

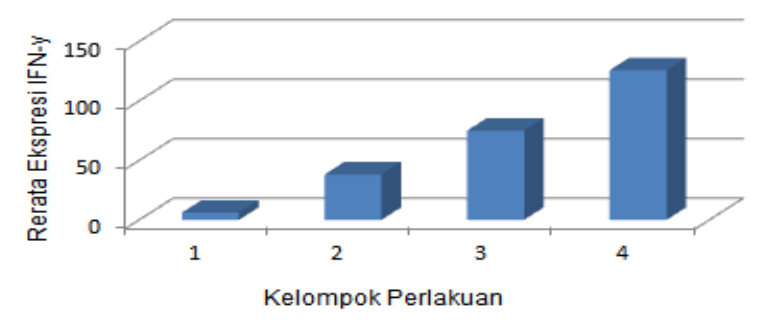

Gambar 3. Ekspresi IFN- $p$ pada mencit BALB/C.

Keterangan:

1: Tanpa imunisasi

2: Ajuvan ISCOM $120 \mu \mathrm{g} / \mathrm{mL}$

3: $100 \mu \mathrm{g} / \mathrm{mL}$ protein adhesin $38 \mathrm{kDa}$ M. tuberculosis

4: $100 \mu \mathrm{g} / \mathrm{mL}$ protein adhesin $38 \mathrm{kDa}$ M. tuberculosis dan ajuvanISCOM $120 \mu \mathrm{g} / \mathrm{mL}$

Untuk mendeteksi ada atau tidaknya homogenitas dilakukan dengan menggunakan uji kesamaan ragam yaitu dengan test ofhomogenecity of variances. Hasil nilai signifikansi ( $p$ ) dari uji homogenitas sebesar 0,000 $(p<0,05)$, maka dapat disimpulkan bahwa ragam data kadar IFN- $\gamma$ mencit jantan jenis BALB/c berdasarkan faktor perlakuan pemberian $100 \mu \mathrm{g} / \mathrm{mL}$ protein adhesin $38 \mathrm{kDa}$ M. tuberculosis dan/atau ajuvan ISCOM $120 \mu \mathrm{g} / \mathrm{mLtidak}$ homogen, sehingga tidak dapat dilakukan pengujian dengan ANOVA pada tahap berikutnya. Uji komparasi alternatif yang digunakan pada penelitian ini adalah uji non-parametrik Kruskal-Wallis. Pada Tabel 1, terlihat bahwa pada setiap perlakuan pemberian ISCOM, adhesin maupun ISCOM dan adhesin menunjukkan ekspresi IFNyang lebih tinggi dibandingkan tanpa imunisasi. Analisis statistik dengan Kruskall Wallis menunjukkan bahwa terdapat perbedaan ekspresi IFN- $\gamma$ pada semua kelompok perlakuan. Uji perbandingan multipel Mann Whitney menyatakan bahwa terdapat peningkatan ekspresi IFN- $\gamma$ secara signifikan dalam kombinasi protein adhesin dengan ajuvan ISCOM (mean $\pm S D=126 \pm 17, p=0,000$ ) bila dibandingkan dengan kelompok lain. Paparan dengan ISCOM saja mampu menginduksi ekspresi IFN- $\gamma$ secara signifikan bila dibandingkan dengan kontrol $(p=0,000)$.

Tabel 1. Ekpresi IFN- $\gamma$ Mencit BALB/C

\begin{tabular}{lcc}
\hline \multicolumn{1}{c}{ Kelompok } & N & Rerata \\
\hline Tanpa imunisasi & 25 & 13,00 \\
ISCOM & 25 & 48,34 \\
Adhesin & 25 & 53,40 \\
ISCOM + adhesin & 25 & 87,26 \\
Total & 100 & \\
\hline
\end{tabular}

\section{DISKUSI}

Pemberian imunisasi melalui oral memiliki beberapa keuntungan dibandingkan pemberian melalui injeksi subcutaneous atau intradermal, diantaranya adalah pemberian yang non invasive, dapat mengurangi risiko penularan infeksi melalui darah, dan relatif mudah dilakukan oleh individu meskipun tanpa bantuan petugas medis (13). Keuntungan vaksin oral pada anak-anak tampaknya merupakan bukti yang paling besar, dimana menunjukkan adanya induksi imunitas sistemik yang baik (8). Oleh karena alasan tersebut, pemberian vaksinasi yang 
digunakan pada penelitian ini adalah melalui oral.

Respon imun terhadap vaksin dipengaruhi oleh beberapa hal diantaranya rute imunisasi (oral atau injeksi), bentuk antigen (live, killed, soluble, subunit peptide, particular, dII), dan adanya elemen biologi aktif yang mampu memperantarai specific tissue tropisms. Selain itu, kandungan ajuvan, vector, atau vehicle juga cukup mempengaruhi kualitas dan kuantitas respon imun (14). Banyak protein antigen selain menimbulkan oral tolerance juga dapat menurunkan respon imunogen yang jelek bila diberikan secara oral. Ajuvan merupakan pelengkap vaksin yang bertujuan untuk meningkatkan respons imun tubuh (9). ISCOM merupakan salah satu jenis ajuvan yang dapat meningkatkan imunogenitas imunogen yang jelek bila digabung dan diberikan secara oral. Penggunaan ISCOM sebagai ajuvan mampu meningkatkan aktivitas sistem imun, khususnya menginduksi respon CTL CD8+ dengan memfasilitasi masuknya antigen kedalam cytosol. Pemberian ISCOM tidak toksik, terutama bila vaksin ini dicobakan pada manusia. Beberapa studi telah dilakukan dengan pemberian ISCOM secara peroral mampu memberikan efektifitas yang sama dengan pemberian per injeksi (9).

ISCOM mampu meliputi antigen dan membuat partikel memiliki ukuran yang lebih besar, selain sebagai kendaraan antigen dan untuk melindungi antigen agar tidak terdegradasi pada lambung, ukuran partikel yang besar juga memudahkan antigen untuk di uptake ke dalam Peyer's patch serta bermigrasi ke paru. Selain itu, ISCOM terdiri dari lipid (kolesterol, phospolipid) yang dapat memudahkan antigen yang diselimutinya untuk menembus membran mukosa, sehingga dapat menginduksi respon imun mukosal (9). Clark et al membuktikan bahwa bahwa lipid memegang peranan penting dalam perlindungan terhadap vaksin yang masuk melalui oral (15). Dobakhti dalam penelitiannya juga membuktikan bahwa vaksin yang diberikan melalui oral harus dilindungi. Hal ini bertujuan untuk mencegah degradasi vaksin pada lambung dan meningkatkan efisiensi vaksin yang melewati mukosa GIT untuk proses dan presentasi sistem imun (16). Ajuvan secara teoritis dikatakan hanya sebagai pelengkap untuk dikombinasikan dengan vaksin antigen yang berperan dalam menginduksi respons imun tubuh. Satu hal penting dalam mekanisme peningkatan respon imun oleh ajuvan (termasuk ISCOM) adalah kemampuan ajuvan untuk berinteraksi dengan APC, sehingga mampu mempresentasikan respon imun (9).

Model hewan coba yang digunakan pada penelitan ini adalah mencit BALB/c. Hal ini berdasarkan penelitian terdahulu oleh Doherty et al, Wang et al, maupun Tandya, yang menggunakan mencit BALB/c untuk menilai respon imunitas terhadap $M$. tuberculosis yang diinfeksikan $(8,13,17)$. Penelitian lain juga melaporkan bahwa mencit BALB/C sangat baik dipakai sebagai model infeksi pada penyakit pernafasan dan merupakan hewan model yang bagus dalam penelitian-penelitian uji kandidat vaksin, karena memiliki respon imun yang baik dibandingkan hewan coba lainnya (18).

Pemilihan penggunaan protein adhesin $38 \mathrm{kDa} M$. tuberculosis dengan dosis $100 \mu \mathrm{g} / \mathrm{mL}$ adalah berdasarkan penelitian terdahulu oleh Tandya. Protein 38-kDa $M$. tuberculosis diperoleh dari hasil isolasi dinding sel dan terbukti memiliki titer hemaglutinasi paling tinggi serta merupakan protein adhesin, sehingga protein ini dikatakan memiliki sifat imunogen tertinggi dibandingkan protein dinding sel M. tuberculosis lainnya (8). Antigen 38-
kDa merupakan non-secretory lipoprotein. Protein ini bersifat spesifik yang berarti hanya terdapat pada $M$. tuberculosis dan tidak terdapat pada Mycobacterium lainnya. Protein tersebut juga dapat menginduksi respons antibodi dan respons sel T yang kuat untuk mencegah infeksi M. tuberculosis pada mencit (19). Dosis $100 \mu \mathrm{g} / \mathrm{mL}$ merupakan dosis optimum yang diperoleh dari hasil eksplorasi oleh Tandya. Bila protein adhesin $38 \mathrm{kDa}$ diberikan dengan konsentrasi lebih dari $100 \mu \mathrm{g} / \mathrm{mL}$ akan menyebabkan lesi pada usus mencit (8).

Ditinjau dari segi imunologik, mukosa merupakan port $d^{\prime}$ entree dari $M$. tuberculosis dan mukosa paru dilindungi oleh sistem limfoid yang khusus, yaitu BALT (the BronchusAssociated Lymphoid Tissue). Imunisasi melalui satu jenis permukaan mukosa akan menginduksi sistem imun di permukaan mukosa lainnya, sebagai contoh imunisasi per oral yang melalui mukosa Gastro-Intestinal Tract (GIT) akan memberikan proteksi yang sangat tinggi terhadap mukosa paru (13). Czerkinsky dan Holmgren, menyebutkan istilah "Common Mucosal Immune System", yaitu imunitas yang timbul di suatu membran mukosa juga efektif di membran mukosa lainnya (20). Jaringan limfoid pada BALT mirip dengan GALT dan ditemukan di percabangan-percabangan saluran nafas (21). Vaksin BCG yang diberikan per oral akan melewati intestinal barrier yaitu sel $M$ dari Peyer's patches (PP), yang akan menginduksi respon imun berupa sel limfosit di lien, mesenteric lymph nodes (MLN), dan PP itu sendiri (15). Sel limfosit tersebut akan terdistribusi ke sistem limfoid lainnya (termasuk BALT) melalui saluran limfe dan pembuluh darah (22). Pada penelitian yang dilakukan oleh Youet al, bahwa protein $19-\mathrm{kDa}$ dan $38-\mathrm{kDa} M$. tuberculosis yang diekspresikan melalui rekombinan vaksin virus, efektif dalam menginduksi respons imun antiTB. Pemberian protein $38-k D a$ melalui vaksin nucleic acid dapat menginduksi respons imun berupa IFN- $\gamma$ dan respons kuat sel CTL CD8+ (23).

Pada kelompok IV (imunisasi per oral dengan protein adhesin 38-kDa M. tuberculosis $100 \mu \mathrm{g}$ dan ISCOM $12 \mu \mathrm{g}$ ) didapatkan sekresi IFN- $y$ yang signifikan dibanding kelompok kontrol $(p=0,00$ yaitu $p<0,05)$ yang pada pewarnaan imunohistokimia tampak berwarna kecoklatan pada membran sel. Hal tersebut menunjukkan bahwa protein adhesin 38-kDa $M$. tuberculosis dapat menginduksi respons imun seluler berupa peningkatansekresi IFN- $\gamma$ (23). Penggunaan ajuvan sebagai pelengkap dari vaksin untuk meningkatkan respons imun tubuh. Hal yang terpenting dari ajuvan yaitu kemampuannya mengaktivasi APC (9). Ajuvan dikombinasikan dengan vaksin antigen untuk menginduksi respons imun yang kuat. Ajuvan berfungsi untuk menginduksi respons imun lebih awal, lebih kuat dan tinggi, serta lebih lama sebagai proteksi tubuh terhadap infeksi penyakit (24). Manfaat dari pemberian protein yang dikombinasikan dengan ISCOM antara lain memperkaya atau memperbanyak ikatan molekul membran, mempresentasikan protein dengan tepat sehingga dapat dikenali oleh sistem imun, meningkatkan uptake protein, serta meningkatkan induksi CTL $(25,26)$.

Sebuah studi menemukan bahwa ISCOM dapat meningkatkan ekspresi MHC pada sel APC karena presentasi antigen yang tepat. ISCOM dapat menginduksi kadar antibodi yang tinggi dan respons sel $\mathrm{T}$ yang kuat terutama sel Tcytotoxic pada beberapa penelitian eksperimental pada hewan coba (9). Ajuvan ISCOM mempunyai banyak keunggulan, akan tetapi ISCOM juga menimbulkan efek samping. Toksisitas saponin dalam 
ISCOM jika diberikan sebagai vaksin terhadap manusia dan hewan menjadi permasalahan yang diberdebatkan pada kurun waktu tertentu. Pada mencit dan tikus, saponin Quil A hanya memberikan efek peningkatan berat badan jika diberikan per oral dan bersifat toksik jika diberikan parenteral pada pemberian dosis yang berlebih (dosis yang seharusnya diberikan untuk hewan besar). Pemberian Quil A pada ISCOM atau QS-21 secara parenteral mempunyai efek toksik yang sangat kecil pada beberapa hewan besar antara lain ayam, kucing, kera, anjing, kambing, domba, dan kuda. Pemberian ISCOM tidak menyebabkan hemolisis dari sel darah merah ayam secara in vitro pada dosis $100 \mu \mathrm{g} / \mathrm{mL}$. Hemolisis yang cukup banyak terjadi pada pemberian Quil A bebas atau QH-B dan QH-C yang tidak terikat pada ISCOM. Pemberian vaksin dengan Quil A yang terikat pada ISCOM menimbulkan respons inflamasi yang sangat rendah dibandingkan dengan pemberian vaksin hanya dengan Quil A bebas. Menurut Sjölander et al, maka penggunaan ajuvan ISCOM aman dan efektif jika dicobakan kepada manusia berdasarkan data-data dari studi yang mereka lakukan (9).

Pada kelompok III (imunisasi per oral dengan protein adhesin 38-kDa M. tuberculosis $100 \mu \mathrm{g}$ ) didapatkan sekresi IFN- $\gamma$ yang signifikan dibandingkan kelompok kontrol $(p=0,00$ yaitu $p<0,05)$ dan kelompok II $(p=0,00$ yaitu $p<0,05)$. Akan tetapi sekresi IFN- $\gamma$ berkurang $40 \%$ dari kelompok IV. Pada penelitian yang dilakukan oleh Zubaidah hasil penelitian menunjukkan bahwa pada pemberian SPT Ag intranasal dengan atau tanpa ajuvan CT terdapat perbedaan gambaran respon imun IgA yang signifikan $(p<0,05)$, dibandingkan PBS sebagai kelompok kontrol. Penggunaan SPT Ag tanpa ajuvan meningkatkan respon imun yang nyata terutama pada minggu I sebesar 0,669 , yang kemudian menurun pada minggu-minggu selanjutnya. Penggunaan SPT Ag dengan ajuvan CT, menghasilkan respon imun yang rendah pada minggu I yaitu 0,386 tetapi diikuti peningkatan yang signifikan $(p<0,05)$, pada minggu III $(0,632)$, yang merupakan puncak respon IgA tertinggi, kemudian menurun secara tidak signifikan $(p>0,05)$ pada minggu berikutnya yaitu 0,551 (25).

Pada kelompok II (imunisasi per oral dengan ajuvan ISCOM $12 \mu \mathrm{g}$ ) didapatkan sekresi IFN- $\gamma$ yang lebih tinggi secara signifikan dibandingkan kelompok kontrol $(p=0,000$ yaitu $p<0,05)$. Hal tersebut karena meski ajuvan hanya sebagai pelengkap yaitu dikombinasikan dengan vaksin antigen untuk menginduksi respons imun tubuh, namun ajuvan mampu merangsang respon imun tubuh seperti yang telah dijelaskan di atas. Peningkatan respon imun oleh ajuvan (termasuk ISCOM) adalah kemampuan ajuvan untuk berinteraksi dengan APC, sehingga mampu mempresentasikan respon imun (9). Kata ajuvan berasal dari bahasa latin yaitu ajuvan yang berarti "to help".

Pada kelompok I (kontrol, tidak diimunisasi) didapatkan sekresi IFN- $\gamma$ sangat sedikit. Pada saat inspirasi, udara yang masuk tidak hanya mengandung oksigen, tapi juga mengandung beberapa partikel asing, gas toksik, dan

\section{DAFTAR PUSTAKA}

1. Depkes. Pedoman Nasional Penanggulangan Tuberkulosis. Edisi 2. Jakarta: Departemen Kesehatan RI; 2007.

2. World Health Organization. Global Tuberculosis Control. WHO Report 2011. (Online) 2011. http://www.who.int/tb/publications/global_report/ mikroorganisme. Untuk fungsi pertukaran gas di paru, maka benda asing tersebut harus dihilangkan atau dibuang dengan suatu sistem pertahanan tubuh mulai dari hidung sampai alveoli agar tidak timbul suatu inflamasi. Secara skematik, komponen pertahanan paru bisa berada di saluran nafas atas dan di alveoli. Saluran nafas atas dan bronkus besar menjaga paru dengan suatu barier yang berhubungan dengan mekanisme reflek batuk, mucociliary apparatus, dan mensekresi imunoglobulin $A$ (IgA). Pada saluran nafas bawah termasuk alveoli, pertahanan tubuh berupa membran superfisial pada mukosa, sel dendritik yang dapat menangkap organisme atau partikel yang masuk ke dalam paru dan membawanya ke lymph nodes di sekitar saluran nafas atau di hilus. Pada bronkhiolus, partikel atau organisme yang masuk ditangkap oleh makrofag dan juga terdapat IgG, komplemen, fibronektin, sel neutrofil, dan sel limfosit. Sekresi IFN- $y$ pada kelompok kontrol merupakan suatu hal yang normal terjadi pada hewan dan manusia yang sehat (26).

Pada penelitian ini hanya menggunakan dosis protein adhesin 38-kDa M. tuberculosis yaitu $100 \mu \mathrm{g}$ (merupakan dosis optimal yang aman digunakan). Analisis data dilakukan secara kuantitatif dengan menghitung sekresi IFN- $\gamma$ yang berwarna kecoklatan pada membran sel dengan pengecatan imnohistokimia. Secara kuantitatif pemberian protein adhesin 38-kDa M. tuberculosis $100 \mu \mathrm{g}$ dapat meningkatkan sekresi IFN- $\gamma$. Penelitian ini belum menggambarkan efek protektif pada masing-masing perlakuan. Meskipun kombinasi antara ISCOM dengan protein adhesin $38-\mathrm{kDa} M$. tuberculosis memberikan peningkatan ekspresi IFN-y, namun hal tersebut belum bisa membuktikan memiliki efek protektif terhadap kuman $M$. tuberculosis lebih baik jika dibandingkan dengan tanpa penambahan adjuvan. Penelitian lanjutan perlu dilakukan untuk mengkaji efek protektif vaksin yang dikombinasi dengan adjuvan, dengan terlebih dahulu memberikan paparan kuman $M$. tuberculosis pada subjek yang telah tervaksinasi.

Pemberian protein adhesin 38-kDa Mycobacterium tuberculosis yang diberikan melalui oral dapat meningkatkan ekspresi IFN-ppada paru mencit BALB/c. Pemberian adjuvan ISCOM per oral dapat meningkatkan ekspresi IFN- $\gamma$ pada paru mencit BALB/c. Pemberian kombinasi adjuvan ISCOM dengan protein adhesin 38-kDa mampu meningkatkan ekspresi IFN- $\gamma$ pada paru mencit BALB/c lebih besar secara signifikan dibandingkan dengan pemberian protein adhesin saja atau adjuvan ISCOM saja. Diharapkan ada penelitian lanjutan yang mengkaji mengenai efek protektif vaksin yang dikombinasi dengan adjuvan, dengan mempapar subjek yang telah tervaksinasi sebelumnya dengan kuman Mycobacterium tuberculosis. Penelitian selanjutnya diharapkan mampu menyingkirkan infeksi pada subjek penelitian sebagai variabel pengganggu terhadap ekspresi IFN- $\gamma$, sehingga dapat hampir dipastikan ekspresi IFN- $\gamma$ sebagian besar murni karena perlakuan. 2011/gtbr11_full.pdf [diakses tanggal 15 Januari 2012].

3. World Health Organization. Guidance for National Tuberculosis Program on the Management of Tuberculosis in Children. Chapter 1: Introduction and Diagnosis of Tuberculosis in Children. The International Journal of Tuberculosis and Lung 
Disease. 2006; 10(10): 1091-1097.

4. Kartasasmita C. Epidemiologi Tuberkulosis. Sari Pediatri. 2009; 11(2): 124-129.

5. Ormerod LP. Multidrug-Resistant Tuberculosis (MDRTB): Epidemiology, Prevention and Treatment. British Medical Bulletin. 2005; 73-74: 17-24.

6. World Health Organization. Treatment of Tuberculosis Guide Line. (Online) 2010 http://www.who.int/tb/ publications/global_report/2010/gtbr11_full.pdf [diakses tanggal 5 Januari 2012].

7. Palomino JC, Martin A, and Portaels F. Rapid Drug Resistance Detection in Mycobacterium tuberculosis: A Review of Colorimetric Methods. Clinical Microbiology and Infection. 2007; 13(8): 754-762.

8. Tandya S. Peran Protein Adhesin Mycobacterium Tuberculosis dalam menginduksi Secretory Immunoglobulin A Mukosa Usus dan Brokhiolus Mencit BALB/c. [Disertasi]. Tidak diterbitkan. Fakultas Kedokteran Universitas Brawijaya, Malang. 2006.

9. Sjolander A, Drane D, Maraskovsky EE, et al. Immune Responses to ISCOM Formulations in Animal and Primate Models. Vaccine. 2001: 19(17-19): 26612665.

10. Cooper AM. Cell-Mediated Immune Responses in Tuberculosis. Annual Review of Immunology. 2009; 27: 393-422.

11. Mazurek GH, Jereb J, Vernon A, LoBue P, Goldberg S, and Castro K. Updated Guidelines for Using Interferon Gamma Release Assays to Detect Mycobacterium tuberculosis Infection. Morbidity and Mortality Weekly Report. 2010; 59(RR05): 1-25.

12. Gallegos AM, van Heijst JW, Samstein M, Su X, Pamer $\mathrm{EG}$, and Glickman MS. A Gamma Interferon Independent Mechanism of CD4 T Cell Mediated Control of $M$. tuberculosis Infection In Vivo. PLoS Pathogens. 2011; 7(5): e1002052.

13. Doherty TM, Demissie A, Olobo J, et al. Immune Responses to the Mycobacterium tuberculosisSpecific Antigen ESAT-6 Signal Subclinical Infection among Contacts of Tuberculosis Patients. Journal of Clinical Microbiology. 2002; 40(2): 704-706.

14. Anderson AO. Peripheral and Mucosal Immunity: Critical Issues for Oral Vaccine Design. (Online) 2006. http://artnscience.us/Mucosal_Immunity/ [diakses tanggal 5 April 2011].

15. Clark S, Cross ML, Nadian A, et al. Oral Vaccination of Guinea Pigs with a Mycobacterium bovis Bacillus Calmette-Gue'rin Vaccine in a Lipid Matrix Protects against Aerosol Infection with Virulent Mycobacterium bovis. Infection and Immunity. 2008; 76(8): 3771-3776.

16. Dobakhti F, Ajdary S, Taghikhani M, Rafiei S, Bayati K, and Tehrani MR. Immunization with BCG Encapsulated in Alginate Microspheres. Iranian Journal of Immunology. 2006; 3(3): 114-120.

17. Wang J, Thorson L, Stokes RW, et al. Single Mucosal, but Not Parenteral, Immunization with Recombinant Adenoviral-Based Vaccine Provides Potent Protection from Pulmonary Tuberculosis. The Journal of Immunology. 2004; 173(10): 6357-6365.

18. Berata IK. Mencit BALB/C Dapat Digunakan Sebagai Hewan Model Penelitian Virus Penyakit Jembrana. Bulletin Veteriner Udayana. 2009; 11: 7-11.

19. Baumann S, Nasser Eddine A, and Kaufmann SH. Progress in Tuberculosis Vaccines Development. Current Opinion in Immunology. 2006; 18(4): 438-448

20. Hitchick NC. Tuberculosis: Prospects for an Oral Vaccine Using Novel Antigens and Adjuvants. (Online) 2011. http://www.scielo.br/pdf/mioc /v100n5/v100n5a02.pdf. [diakses tanggal 5 April 2011].

21. Price SA and Wilson LM. Patofisologi: Konsep Klinis Proses-Proses Penyakit. Edisi 6. Jakarta: EGC; 2006.

22. Nicod LP. Lung Defences: An Overview. European Respiratory Review. 2005; 14(95): 45-50.

23. You Q, Jiang, C, Wu Y, et al. Subcutaneous Administration of Modified Vaccinia Virus Ankara Expressing an Ag85B-ESAT6 Fusion Protein, but not an Adenovirus-Based Vaccine, Protects Mice Against Intravenous Challenge with Mycobacterium Tuberculosis. Scandinavian Journal of Immunology. 2012; 75(1): 77-84.

24. West E. A Glimpse into the Scary World of Vaccine Adjuvants. (Online) 2005. http://www.vaclib.org /basic/adjuvants.htm. [diakses tanggal 5 April 2011].

25. Zubaidah M. Peningkatan Titer Imunoglobulin $A$ Mukosa Usus Mencit (Mus musculus) Sesudah Pemberian Protein Soluble Toxoplasma gondii dengan atau tanpa Ajuvan Toksin Kolera secara Intranasal: Penelitian Eksperimental Laboratoris. (Online) 2005. http://adln.lib.unair.ac.id/go.php. [diakses tanggal 5 April 2011].

26. Pilette C, Quadrhiri Y, Godding V, Vaerman JP, and Sibile Y. Lung Mucosal Immunity: Immunoglobulin-A Revisit. European Respiratory Journal. 2001; 18: 571-588. 